\title{
Podcast Applications in Language Learning: A Review of Recent Studies
}

\author{
Md. Masudul Hasan ${ }^{1} \&$ Tan Bee Hoon ${ }^{1}$ \\ ${ }^{1}$ Faculty of Modern Languages and Communication, Putra University, Malaysia \\ Correspondence: Associate Professor. Dr. Tan Bee Hoon, Faculty of Modern Languages and Communication, \\ Putra University, Malaysia. Tel: 603-8946-8911. E-mail: tanbh@fbmk.upm.edu.my
}

Received: December 15, 2012 Accepted: December 31, 2012 Online Published: January 9, 2013

doi:10.5539/elt.v6n2p128 URL: http://dx.doi.org/10.5539/elt.v6n2p128

\begin{abstract}
Many dynamic approaches have emerged due to computer technology in facilitating language learning skills. Podcasting is one such novel tool being exploited by teachers to deliver educational content and to encourage learning outside the classroom. Research on podcasting pedagogy suggests that podcasting greatly helps learners develop various skills of English language. The study reviewed twenty journal articles to determine the effects of podcast on ESL students' language skills and attitude levels. It was found that podcasts greatly support learning not just in speaking and listening but also in other language skills and areas such as grammar, pronunciation and vocabulary.
\end{abstract}

Keywords: podcast, computer-assisted language learning (CALL), second language acquisition, attitude, motivation

\section{Introduction}

Podcasting is one of the powerful, emergent technological mediathat has been used in education for many years. Language learning has been recognized as one of the fields about to get help from the rapid development in podcasting. Research studies on podcasting have already acknowledged its potentiality and have documented many evidences that podcasts can greatly help develop learners' language skills, especially in developing learners' speaking and listening skills (Ashton-Hay \& Brookes, 2011; O'Bryan \& Hegelheimer, 2007). The purpose of this review study is to gauge the effects of podcasts on various skills of language and to show how podcasts can contribute to the learning of skills in English. The findings of the review will be helpful for students, teachers, stakeholders, and researchers to adopt this innovative technology for language learning and teaching. The review follows Creswell's (1994) model of reviewing literature that states that the purpose of a review is usually designed to sum up the knowledge concerned and to spotlight relevant facts and issues that have left unsettled.

\subsection{Defining Podcast}

The term podcast is a combination of the terms pod (i.e., from the Apple iPod) and broadcast (Oxford Advanced Learner's Dictionary, 2007). Podcasts are series of digital audio and video recordings uploaded on the web with the aid of Rapid Simple Syndication (RSS) feeds (Lafferty \& Walch, 2006). RSS feeds allow listeners to download their favourite podcasts using podcatcher software like iTunes. Listeners do not need to visit every website frequently for new podcast episodes; they can now find a huge collection of podcasts on iTunes store. Many types of podcasts are found on the Internet such as television podcasts, radio podcasts, classroom podcasts, and individual or group podcasts. Television podcasts, radio podcasts and classroom podcasts are existing programs and lectures turned into podcasts such as those created by VOA (Voice of America). Individual or group podcasts are real podcasts designedfor multiple purposes such as those created by the website http://grammar.quickanddirtytips.com/.

\subsection{Second Language Acquisition and Podcasting Pedagogy}

This part of the analysis aims to briefly examine the theories of second language acquisition (SLA) and to suggest a way to bridge the gap between SLA theories and podcasting pedagogy and practices. There are several approaches and theories of second and foreign language acquisition that have had enormous impact on learning a language. Podcasting does not prescribe any approach or method of language learning, rather, as a tool it can be 
used to integrate theories and methods of SLA into practices. Constructivist view of learning infers that learning is an active process and individual constructs knowledge through observation, interpretation and exploration (Cooper, 1993). According to Rosell-Aguilar (2007), the podcast technology is strongly connected with constructivist approaches to learning, where an individual constructs knowledge through active exploration, observation, processing and interpretation.

Podcasts offer language learners with samples of real language and authentic materials (Thorne \& Payne, 2005). Students can use podcasts as a supplement to their textbook materials (Stanley, 2006). According to Warschauer and Healey (1998), integration of computer-assisted language learning (CALL) technology helps learners learn language in a real, meaningful, authentic situation. The socio-cognitive view of language learning stresses real language use in a meaningful, authentic context. Most of the podcasts found on the Internet are considered real and authentic. Computer-based vodcasts can deliver combinations of text, sound, still images, graphics, animations, video and so on. Moreover, the interactionists believe that the basic element for successful language acquisition is input. Krashen (1985) states that language is acquired in only one way by receiving comprehensible input, that is, by understanding messages. Several CALL research studies carried out within an input perspective have attempted to explain the meaningful input from podcasts that is helpful for learners.

\section{Methodology of Review}

Electronic searches were performed using the following databases: ProQuest Dissertations and Theses, Taylor \& Francis, J-stor, Oxford Journals Online, ERIC, Cambridge Journals Online, SAGE Journals Online, SpringerLink, and Britannica. Search strategies employed included keyword search such as: "podcast", "podcast and language learning" "effects of podcasts on language skills"and "mobile-assisted language learning". A total of 60 articles were downloaded from the online databases. Of these 60 articles, 40 were excluded because they were review, opinion, or editorial papers and were considered non-empirical papers.Articles on podcast that dealt with subjects other than second language acquisition were also discarded. Only research studies on podcast and language learning and teaching were included and reviewed. Moreover, another criterion for the selection of the articles is that they should report studies that are original and empirical.Eventually twenty research articles on podcasting were selected and reviewed to determine the effects of podcasts on student achievement and attitude. Each article was screened and analysed using the constant comparative method proposed by Lincoln and Gub (1985). By following the constant comparative method, the review attempted to compare all the data gathered from the selected research studies.

Appendix A shows a list of the research articles with brief details of the authors, year of publication, research objectives and methodology, types of data and sample size. Out of the 20 research studies, only 4 were found to be experimental or quasi-experimental that analsysed the effects of podcasts on students' English language skills. The remaining studies were descriptive studies designed to investigate students' perceptions, opinion, and attitudes towards podcasts.

This review followed a grounded approach or constant comparative method to analyse each article. Using this method, the coding scheme emerged inductively after reading each paper. Specifically, the grounded approach comprises the following steps: examining each individual article, forming various categories, comparing categories, and achieving category saturation. For instance, the review of articles began by selecting the first article, reading it, and noting its content to form a tentative research topic category. After getting the theme of the first article, then the next article was read and compared to the theme of the first article. When the theme of both articles was found similar, then the review proceeded to the third article. If not, another theme was created. Each article was scrutinized and compared with each other. A total of 20 research articles were read thoroughly and content analysis was done by summarizing the major findings of the studies. After analysing the content of the selected articles, the study identified two major themes. The first theme is concerned with the effects of podcasts on students' language skills. The second theme included learners' attitudes and perceptions towards podcasts. Table 1 shows the list of themes and relevant sub-themes.

Table 1. List of podcast research themes found in the reviewed literature

\begin{tabular}{ll}
\hline Themes & Sub-themes \\
\hline 1. Effects of podcasts on learners' language skills & $\begin{array}{l}\text { Effective Outcomes: Pronunciation, phonetics, } \\
\text { vocabulary, grammar, listening comprehension. }\end{array}$ \\
\hline 2. Learners' perceptions towards podcasts & $\begin{array}{l}\text { Attitudes, opinions, motivations, learning styles and } \\
\text { strategies, barriers and institutional aspects }\end{array}$ \\
\hline
\end{tabular}




\section{Findings from the Review}

Research studies on podcasts in language learning have identified its potentiality in developing learners' language skills (O'Bryan \& Hegelheimer, 2007; Li, 2010). Podcast can accelerate language learners' learning not just in listening but also in other language areas such as pronunciation, vocabulary, grammar, speaking and related learning activities (Chan et al. 2011; Kaplan-Leiserson, 2005). Ashton-Hayand Brookes (2007) state that podcasting facilitates self-paced learning as well as gives slower learners a platform for remediation. Kaplan-Leiserson (2005) points out that podcasting can provide another medium for material review and can assiststudents to develop their language skills. DucateandLomicka (2009) state that podcasting can function as a tool for developing students' pronunciation.

\subsection{Effects of Podcasts on Students' Language Skills}

Podcasts provide teachers with the possibilities of facilitating language learning and also challenge the traditional teaching and learning methods. Traditional classrooms do not give more importance to listening activities (Lee \& Chan, 2007). Podcasts can be used as supporting materials along with the course materials to develop students' proficiency in English (Istanto, 2011; Lee \& Chan, 2007). The use of mobile technology in ESL contexts has become popular in many secondary and higher secondary institutions (Abdous, 2009). Abdous (2009) compared the academic benefits of incorporating podcasts into the curriculum and using them as a supplemental/review tool. The study suggested that podcast technology has the potential to provide greater benefits if it is used more than simply as a tool for reviewing.

Hawke (2010) developed an independent listening pilot course based on podcasts to see how science students can develop their scientific English listening skills through podcasts. Findings of Hawke's (2010) study showed that students' post test scores were significantly higher than the pre-test scores. Podcasts as supplementary materials helplearnerspay attention on the podcast content, and encourage them to listen to podcasts both from top-down and bottom-up perspectives (Hawke, 2010). Similarly, Ashraf, Noroozi and Salami (2011) also investigated the effect of listening to podcasts on the listening skill of some Iranian EFL sophomores. Data were collected through various means: pre- and post-tests, interview, and students' reflective diaries. The findings of the study showed that participants in the experimental group who used podcasts for their listening activities outperformed the ones in the control group. The researchers documented positive attitudes of the participants who used podcasts for listening, and concluded that podcast can be used to improve the listening skill of ESL learners.

Istanto (2011) designed five podcast units as supplementary materials to develop learners' listening skills and grammar knowledge. A questionnaire was administered at the end of the semester to 20 undergraduate students who learned Indonesian as a foreign language. The result indicated that the application of podcast enhanced students' listening skills and grammar knowledge as well as knowledge of the culture of the target community. Hence, podcasting is a novel technology with huge potentials in improving students' listening skills (Artyushina et al., 2011). Students can download authentic podcast materials from the Internet that allow students to be engaged in plenty of listening practice (Artyushina et al., 2011).

Many podcast resources are found on the Web that has broadened an infinite array of possibilities about how to develop listening competence. Kan (2011) analysed a language learning website for developing learners' listening competence. The Centre for English Language Education (CELF) listening website was evaluated by creating a set of evaluation criteria.The study analysed both traditional materials and Web resources in order to find out the strengths and weaknesses of the CELF website. Kan (2011) suggested that designers of Web contents should clarify their purpose, organize the contents and enrich its exercises frequently in order to meet the need of learners in developing their listening skills.

Podcasts can also be used as a tool for developing students' pronunciation. Ducate and Lomicka (2009) conducted a mixed method study to investigate the effects of using podcast to develop students' pronunciation. A total of 22 students in intermediate German and French courses developed five podcasts throughout the semester. Pre and post Pronunciation Attitude Inventory (PAI) surveys were used to assess students' attitudes toward pronunciation. Findings of the study suggested that the respondents' pronunciation did not improve significantly in terms of comprehensibility due to course time limit. However, the students' attitudes towards English language learning increased significantly after using the podcast materials. Similarly, Knight's (2010) study examined the use of podcasts for phonetics exercises. A total of 36 respondents participated and 11 podcasts of graded phonetics were developed and uploaded to the website for students. Students of this project found the exercises of podcasts very effective for developing their phonetics. They liked the ability to repeat the recordings 
many times and felt that there was improvement in their confidence in their transcription and test scores due to the use of podcasts.

Podcast effects were also seen in vocabulary learning. Second language acquisition largely depends on the development of vocabulary (Krashen, 1993; Putman \& Kingsley, 2009). Krashen's (1993) input hypothesis postulates that vocabulary can be acquired by reading as long as the input is comprehensible to the learner. Vocabulary learning has always been considered a popular topic in CALL programs, and is believed likely to be benefited from the rapid developments in podcasting. Vocabulary learning could be easily integrated into podcast programs. Borgia's (2010) study showed that podcast can greatly reinforce students' vocabulary learning. Similarly, the findings of Putman and Kingsley's (2009) study also supported that podcast as a learning tool can greatly help students to improve their vocabulary. Respondents of Putman and Kingsley's (2009) study were of the opinion that podcasts made them more motivated to learn science vocabulary.

\subsection{Perceptions and Attitudes toward Podcasts}

Language learning is influenced by many factors and the most significant and facilitating factor is positive attitude (Mian, 1998). It is sometimes difficult to motivate students outside the classroom, but the use of podcasts can assist this issue. Podcasts have the potentiality to create both intrinsic and extrinsic motivation among students (O-Bryan and Hegelheimer 2007). Kavaliauskiené and Anusiené (2009) used survey questions to examine learners' perceptions of online listening to podcasts. The participants of this study were taken from Mykolas Romeris University, Lithuania. Most of the participants $(76 \%)$ showed positive attitudes to the techniques of developing listening skills using podcasts.

Kim and King (2011) claimed that students and teachers' attitudes toward podcasts varied depending on their previous experiences with various types of computer technologies.Kim and King's (2011) case study of three ESOL teacher candidates investigated questions regarding their attitudes, responses, actions and perceptions toward the use of podcasts and blogs in a core assignment. Interviews, observations, research field notes, dialogues, emails and a pre-term anonymous survey were used to collect data. Kim and King's study explored how teachers integrate podcast and blog while developing a case study for a specific English language learner (ELL) in a real-life classroom context. Similarly, Chan et al. (2011) investigated two podcast projects conducted at a university in Singapore, designed to supplement classroom instruction for Chinese and Koreans as a foreign language. A semi-structured interview was conducted to ascertain their perceptions of the podcasts' quality and usefulness. Chan et al. inferred that respondents who used podcasts on the move or outside their abodes had significantly positive attitudes towards podcasts and found to be interested to podcast-based learning after the exposure to the podcast course.

The use of podcasts also reduces students' anxiety and creates a sense of belonging to a learning community (Chan \& Lee, 2005). Lord (2008) evaluated a joint project on podcasts in an undergraduate phonetic class to assess students' pronunciation and attitudes. The findings concluded that majority of the students enjoyed the project and valued the feedback they received from their peers. Moreover, a significant increase in attitude was found among the participants over the course of the semester.

Moreover, podcasts provide students with a more authentic and personal experience to learn various skills of English language (Li, 2010). Participants of Li's (2010) study stated that they enjoyed listening to podcasts and showed willingness towards this new technology in developing their language skills. Students might have problem with the length and style of podcasts. Chan et al. (2006) suggest that the length of each podcast should be about five minutes, roughly the length of a typical song. Stephens (2007) suggests that teachers can create podcasts in accordance to learners' preferences as podcasts do not need much equipment to create. Borgia (2010) showed how to write a podcast script and how to create a podcast using various types of software program.

Early research studies on Computer-assisted language learning (CALL) claimed that the success of implementing new technologies into any teaching and learning environment depends greatly on the level of commitment and engagement of the related groups: teachers, administrators, stockholders, and curriculum and material designers (Warschauer \& Healey, 1998). O’Bryan and Hegelheimer (2007) describe a planned effort to incorporate podcasts materials in an ESL listening strategies course. Podcasting has the potential to not only act as a rich source of input and instruction for students in the language classroom, but also to transform instruction. Preliminary evaluation of O'Bryan and Hegelheimer's (2007) ongoing project inferred that both the teacher and the students found the podcast a positive component of the language course.

Podcasts were also studied in relation to leaning strategies. It was said no single set of learning strategies results in successful language learning; rather learners use various types of learning strategies in order to be successful language learners (O'Malley \& Chamot, 1990). Cognitive, metacognitive and socio-affective are the three types 
of important learning strategies that learners use (O'Malley \& Chamot, 1990). Ashton-Hay and Brookes (2011) conducted an action research aimed at finding out learning strategies of using podcasts created by students. Participants of the study created a web page in the Queensland University of Technology (QUT) Blackboard Learning Management System (LMS), where the podcasts, story transcripts and student photos were uploaded. Ashton-Hay and Brookes (2011) concluded that the use of various types of learning strategies could facilitate learning of a language. Language teacher does not have enough time to provide sufficient feedback to meet every learner's individual needs. Learning a language does not take place in the classroom. Rather with podcasts, learning can be anywhere and anytime.

Edirisingha (2007) showed the benefits of using podcasts within a first-year undergraduate module on English Language and Communication at Kingston University. Findings of the study clearly indicated that podcasts supported students' preparation for assessed work, and provided valuable advice on portfolio and presentations. Moreover, podcasts helped students in the preparation for workshops and seminars. Students' lack of familiarity with Web 2.0 technologies such as podcasts can be an explanatory reason for the low level of listening to podcasts (Edirishingha, 2007).

\section{Discussion}

In earlier times, a trait of learning and teaching listening was to use professionally produced newscasts, radio, and/or TV programs. With new computer technologies and Internet resources such as podcasts, audioblogs, i-pods, and two-way synchronous video recording, English language learners are now able to learn and control language through the creation of their own video-and audio-casting projects. English language learners should look for podcasts as such materials provide students with plenty of meaningful language, real-world communication, and access to new information.

There are various ways to locate and download podcasts. The most popular way is to subscribe to a podcast by using iTunes in Apple software. Users can download the free iTunes software to their computers. Language learners can also subscribe to, download, and listen to existing podcasts. In addition, teachers and students can create podcasts of their own. There are many podcast resources already available online; some are specific to language learning and some are designed for native speaking audiences. The important point is that podcasts designed by native speakers of English provide learners many chances to listen real and authentic materials. Podcasts designed for English language learning include grammar tips, vocabulary, themes based podcasts, pronunciation, and idioms. For example, Grammar Girl -Quick and Dirty Tips for Better Writing is an education podcast series that offers short one-topic English grammar lessons.

The present study reviews research on podcasts in terms of language education, especially its effects on learners' listening skills. Overall findings suggest that learners generally enjoy using podcasts, and like to listen to the podcasts at home as well as outside the classroom using desktop computers or mobile devices. The review also found that most of the studies reviewed were descriptive. Most of the research studies reviewed used a small sample size which may not be able to reveal an exact picture of podcast effects on students' listening comprehension. The main limitation of studies reviewed is that most of the studies based their findings primarily on respondents' self-reported data such as questionnaires and interviews. Ducate and Lomicka (2009) evaluated the effects of using podcasts to facilitate students' pronunciation in second language learning and could not find satisfactory results perhaps because the 16-week long treatment was too short to foster significant improvement. The results of the reviewed studies suggested that the application of podcasting enhanced students' language skills in general, and listening skill in particular. Yet whether the improved listening comprehension and respondents' positive attitudes could be attributed to the use of podcasts was found to be questionable.

However, perceptions and attitudes towards podcasts have been investigated and in most cases, positive attitudes were documented. Majority of the respondents of the reviewed studies hold positive attitudes toward the method of using podcasts in language learning. The vast majority of the respondents stated that the method was exciting that they enjoyed using it. Most of the students acknowledged that the use of podcasts could help improve their language learning skills.

\subsection{Conclusion}

It is clear from the studies that using podcast is more beneficial and helpful than using the traditional chalk and talk method. Numerous research studies on podcasts confirm the efficacy of computer applications in second language learning and teaching contexts, and claim that the integration of podcastin learning can improve academic performance, enhance motivation, and promote learning. Podcast is also considered a powerful learning method in many aspects such as culture and history of the areas where the target language is spoken. Generally, the findings suggest that language learners were positive towards using podcast technology, and they 
were interested to use podcast technology into their language learning processes. Some of the reasons for the positive perceptions included the opportunity for students to learn at their own time, and to listen to specific materials that they miss or do not understand multiple times. Effects, attitudes, and perceptions towards podcasts have been investigated and in most cases, positive effects and attitudes towards podcasting are documented.

\section{References}

Ashraf, H., Noroozi, S., \& Salami, M. (2011). E-listening: The Promotion of EFL Listening Skill via Educational Podcasts, 10-17.

Abdous, M., Camarena, M., \& Facer, B. R. (2009). MALL Technology: Use of Academic Podcasting in the Foreign Language Classroom. ReCALL, 21(1), 76-95. http://dx.doi.org/10.1017/S0958344009000020

Artyushina, G., Sheypak, O., Khovrin, A., \& Spektor, V. (2011). How to Improve Listening Skills for Technical Students. 14th International Conference on Interactive Collaborative Learning (ICL2011), 11th International Conference Virtual University, Slovakia.

Ashton-Hay, S., \& Brookes, D. (2011). Here's a story: using student podcasts to raise awareness of language learning strategies. EA Journal, 26(2), 15-27.

Borgia, L. (2010). Enhanced Vocabulary Podcasts Implementation In Fifth Grade Classrooms. Reading Improvement, 46(4), 263-72. Retrieved from Education Full Text database 263-267.

Chan, W. M., Chi, S. W., \& Lin, C. Y. (2011).Students' Perceptions of and Attitudes towards Podcast-Based Learning - A Comparison of Two Language Podcast Projects. Electronic Journal of Foreign Language Teaching, 8(1), 312-335.

Chan, W. M., Chen, I. R., \& Döpel, M. (2011). Podcasting in foreign language learning: Insights for podcast design from a developmental research project. In M. Levy, F. Blin, C. Bradin Siskin, \& O. Takeuchi (Eds.), WorldCALL: Global perspectives on computer-assisted language learning (pp. 19-37). New York \& London: Routledge.

Chan, A., \& Lee, M. J. W. (2005). An MP3 a day keeps the worries away: Exploring the use of podcasting to address preconceptions and alleviate pre-class anxiety amongst undergraduate information technology students. In D. H. R. Spennemann, \& L. Burr (Ed.), Good Practice in Practice: Proceedings of the Student Experience Conference (pp. 58-70). WaggaWagga, NSW. 5-7 September.

Cooper, D. P. (1993). Paradigm shifts in designing instruction: from behaviourism to cognitivism. Educational Technology, 33(5), 12-19.

Creswell, J. (1994). Research design qualitative and quantitative approaches. Thousand Oaks: Sage.

Ducate, L., \& Lomicka, L. (2009). Podcasting: An Effective Tool for Honing Language Students' Pronunciation?. Language Learning \& Technology, 13(3), 66-86.

Edirisingha, P., Rizzi, C., Nie, M., \& Rothwell, L. (2007). Podcasting to Provide Teaching and Learning Support for an Undergraduate Module on English. Turkish Online Journal of Distance Education, 8(3), 87-107.

Hawke, P. (2010). Using internet- sourced podcasts in independent listening courses: Legal and pedagogical implications. Jalt CALL Journal, 6(3), 219-234.

Istanto, J. W. (2011). Pelangi Bahasa Indonesia podcast: what, why and how? Electronic Journal of Foreign Language Teaching, 8(1), 371-384.

Kan, S. O. (2011). Critique of a Language-Learning Website. US-China Education Review, 8(5), 675-681.

Kaplan-Leiserson. (2005). Trend: Podcasting in academic and corporate learning. Retrieved March $15^{\text {th }}, 2012$ from http://www.learningcircuits.org

Krashen, S. (1985). The Input Hypothesis: Issues and Implication. Longman: New York.

Kavaliauskienė, G., \& Anusienè, L. (2009). English for specific purposes: Podcasts for listening skills. Coactivity: Philology, Educology, 17(2), 28-37. http://dx.doi.org/10.3846/1822-430X.2009.17.2.28-37

Kim, D., \& King, K. (2011). Implementing podcasts with ESOL teacher candidates' preparation: Interpretations and implication. International Forum of Teaching and Studies, 7(2), 5-19.

Knight, R. (2010). Sounds for Study: Speech and Language Therapy Students: Use and Perception of Exercise Podcasts for Phonetics. International Society for Exploring Teaching and Learning, 22(3), 269-276.

Lafferty, M., \& Walch, R. (2006). Tricks of the podcasting masters. New York: Que. 
Lee, M. J. W., \& Chan, A. (2007). Pervasive, lifestyle-integrated mobile learning for distance learners: An analysis and unexpected results from a podcasting study. Open Learning. The Journal of Open and Distance Learning, 22(3), 201-218.

Li, H. C. (2012, February). Using podcasts for learning English: Perceptions of Hong Kong Secondary 6 ESL students. ELT World Online, 4, 78-90.

Lincoln, Y. S., \& Guba, E. G. (1985). Naturalistic inquiry. Beverly Hills, CA: Sage.

Lord, G. (2008). Podcasting Communities and Second Language Pronunciation. Foreign Language Annals, $41(2)$.

McClung, S., \& Johnson, K. (2010). Examining the motives of podcast users. Journal of Radio and Audio Media, $17(1), 82-95$.

Mian, A. H. (1998). Motivation and attitudes of beginning and intermediate level Panjabi students learning English as a second language. Unpublished doctoral dissertation, Indiana University of Pennsylvania, Indiana. PA.

O'Bryan, A., \&Hegelheimer, V. (2007). Integrating CALL into the classroom: The role of podcasting in an ESL listening strategies course. ReCALL, 19(2), 162-180. http://dx.doi.org/10.1017/S0958344007000523

O'Malley, J. M., \& Chamot, A. U. (1990). Learning strategies in second language acquisition. Cambridge: Cambridge University Press.

Oxford Advanced Learner's Dictionary (7th ed.). (2007). Podcast. New York: Oxford University Press.

Putman, S. M., \& Kingsley, T. (2012). The Atoms Family: Using Podcasts to Enhance the Development of Science Vocabulary. The Reading Teacher, 63(2), 100-108. http://domo.1598/RT.63.2.1

Rosell-Aguilar, F. (2007). Top of the pods: In search of a podcasting "podagogy" for language learning. Computer Assisted Language Learning, 20(5), 471-492. http://dx.doi.org/10.1080/09588220701746047

Stanley, G. (2005). Podcasting for ELT. Retrieved from http://www.teachingenglish.org.uk/think/resources/podcast.shtml

Stephens, M. (2007). All about Podcasting. Library Media Connection, 25(5), 54-57.

Thorne, S., \& Payne, J. (2005). Evolutionary Trajectories, Internet-mediated Expression, and Language Education. CALICO, 22(3), 371-397.

Verna, P. (January, 2008). Podcasting advertising: Seeking riches in niches. [Abstract]. Retrieved March 14, 2012, from http://www.emarketer.com/Reports/All/Emarketer_2000474.aspx?srcDreport_head_info_sitesearch

Warschauer, M., \& Healey, D. (1998). Computers and language leaning: An overview. Language Teaching, 31, 57-71.

\section{Appendix A}

\section{Summary of Podcast Research Studies}

\begin{tabular}{|c|c|c|c|c|}
\hline Authors name & Research aim / objective & $\begin{array}{l}\text { Research } \\
\text { method }\end{array}$ & collection & $\begin{array}{l}\text { Sample } \\
\text { size }\end{array}$ \\
\hline $\begin{array}{l}\text { O'Bryan } \\
\text { \&Hegelheimer } \\
(2007)\end{array}$ & $\begin{array}{l}\text { Implemented podcasts into academic English to } \\
\text { find out language learning strategies }\end{array}$ & $\begin{array}{l}\text { Quasi-experim } \\
\text { ental }\end{array}$ & $\begin{array}{l}\text { Survey, pre-and Post } \\
\text { test }\end{array}$ & Not given \\
\hline $\begin{array}{l}\text { Chan et al } \\
(2011)\end{array}$ & $\begin{array}{l}\text { Investigated students' perceptions of and } \\
\text { attitudes towards podcast-Based Learning }\end{array}$ & Descriptive & Questionnaire & 120 \\
\hline $\begin{array}{l}\text { Lee and } \\
\text { Chan } \\
(2007)\end{array}$ & $\begin{array}{l}\text { Assessed the use of podcasts to provide } \\
\text { additional listening materials to distance learners }\end{array}$ & Descriptive & $\begin{array}{l}\text { Survey, } \\
\text { student interview }\end{array}$ & Not given \\
\hline $\begin{array}{l}\text { Artyushina et } \\
\text { al. (2011) }\end{array}$ & $\begin{array}{l}\text { Investigated how students can improve listening } \\
\text { through podcast }\end{array}$ & Descriptive & Survey & 180 \\
\hline $\begin{array}{l}\text { Kennedy } \\
(2011)\end{array}$ & $\begin{array}{l}\text { Scrutinized the effects of using content } \\
\text { acquisition podcasts (CAPs) to provide } \\
\text { vocabulary instruction to adolescents with and } \\
\text { without learning disabilities (LD). }\end{array}$ & Experimental & Preand post tests & 279 \\
\hline $\mathrm{Li}(2010)$ & Examined students' perceptions of using & Mixed & Interview, & 16 \\
\hline
\end{tabular}




\begin{tabular}{|c|c|c|c|c|}
\hline & podcasts to develop language skills & Methods & questionnaire & \\
\hline $\begin{array}{l}\text { Kavaliauskienè } \\
\text { (2009) }\end{array}$ & $\begin{array}{l}\text { Pointed out the difficulties students faced in } \\
\text { listening to various podcasts }\end{array}$ & Descriptive & Survey & 285 \\
\hline $\begin{array}{l}\text { Ashton-hay } \\
\& \quad \text { Brookes } \\
(2007)\end{array}$ & $\begin{array}{l}\text { Evaluated the use of student podcasts to raise } \\
\text { awareness of language learning strategies }\end{array}$ & Descriptive & $\begin{array}{l}\text { Questionnaire, } \\
\text { Interview }\end{array}$ & Not Given \\
\hline $\begin{array}{l}\text { Ducate\&Lomic } \\
\text { ka (2009) }\end{array}$ & $\begin{array}{l}\text { Investigated podcasting as a tool for developing } \\
\text { students' pronunciation }\end{array}$ & Mixed Method & $\begin{array}{l}\text { Survey, preand post } \\
\text { tests }\end{array}$ & 22 \\
\hline Istanto (2011) & $\begin{array}{l}\text { Reported on the use of podcasting as a medium } \\
\text { in language learning to enhance students' } \\
\text { learning experiences beyond classroom } \\
\text { instruction. }\end{array}$ & Descriptive & Survey & 20 \\
\hline Lord (2008) & $\begin{array}{l}\text { Examined the change of students' attitudes } \\
\text { toward foreign language pronunciation after } \\
\text { using podcasts }\end{array}$ & Mixed Method & $\begin{array}{l}\text { Survey, } \\
\text { questionnaire, } \\
\text { preand post tests }\end{array}$ & 19 \\
\hline $\begin{array}{l}\text { Hawke } \\
(2010)\end{array}$ & $\begin{array}{l}\text { Analyzed how science students can improve } \\
\text { their scientific English listening skills using a } \\
\text { portable MP3 }\end{array}$ & Descriptive & Survey & 30 \\
\hline Kan (2011) & $\begin{array}{l}\text { Evaluated language learning website for } \\
\text { developing learners' listening skills }\end{array}$ & Qualitative & Website Contents & 1 \\
\hline Knight (2010) & $\begin{array}{l}\text { Aimed to assess how exercise podcasts for } \\
\text { phonetics are used and perceived by second year } \\
\text { speech and language therapy students }\end{array}$ & Descriptive & Survey & 36 \\
\hline $\begin{array}{l}\text { Edirisingha } \\
(2007)\end{array}$ & $\begin{array}{l}\text { Investigated the benefits of integrating podcasts } \\
\text { into a first year undergraduate module on } \\
\text { English Language and Communication }\end{array}$ & Descriptive & $\begin{array}{l}\text { Interview, } \\
\text { questionnaire }\end{array}$ & 35 \\
\hline $\begin{array}{l}\text { Ashraf, } \\
\text { Noroozi\& } \\
\text { Salami (2011) }\end{array}$ & $\begin{array}{l}\text { Aimed at measuring the effect of using } \\
\text { educational podcasts on the development of } \\
\text { listening skill of some Iranian EFL students }\end{array}$ & Experimental & $\begin{array}{l}\text { Pre and post tests, } \\
\text { Interview }\end{array}$ & 58 \\
\hline Borgia (2010) & $\begin{array}{l}\text { Observed the effects of technology -based } \\
\text { vocabulary instruction }\end{array}$ & Descriptive & $\begin{array}{l}\text { Observation, } \\
\text { Interview }\end{array}$ & \\
\hline $\begin{array}{l}\text { Kim \& King } \\
(2011)\end{array}$ & $\begin{array}{l}\text { Investigated questions regarding students' } \\
\text { actions, attitudes, and perceptions toward the } \\
\text { instructional uses of podcasts and blogs in a core } \\
\text { assignment }\end{array}$ & Case Study & $\begin{array}{l}\text { Observation, } \\
\text { interview }\end{array}$ & 3 \\
\hline $\begin{array}{l}\text { Abdous, } \\
\text { Camarena\& } \\
\text { Facer }(2009) \\
\end{array}$ & $\begin{array}{l}\text { Compared the academic benefits of integrating } \\
\text { podcasts into the curriculum against using them } \\
\text { as a supplemental/review tool }\end{array}$ & $\begin{array}{l}\text { Quasi-experim } \\
\text { ental }\end{array}$ & Post test, interview & 113 \\
\hline $\begin{array}{l}\text { Putman \& } \\
\text { Kingsley } \\
(2009)\end{array}$ & $\begin{array}{l}\text { Investigated the effects of podcasts to enhance } \\
\text { the development of science vocabulary }\end{array}$ & $\begin{array}{l}\text { Quasi-experim } \\
\text { ental }\end{array}$ & Preand post tests & 58 \\
\hline
\end{tabular}

